Article

\title{
Effect of Processing Conditions on the Properties of Reticulated Porous Diatomite-Kaolin Composites
}

\author{
Sujin Lee ${ }^{1,2}$, Chae Young Lee ${ }^{1}$, Jang-Hoon Ha ${ }^{1, *,+}$, Jongman Lee ${ }^{1}$, In-Hyuck Song ${ }^{1}$ and \\ Se-Hun Kwon $2, *,+$ \\ 1 Powder and Ceramics Division, Korea Institute of Materials Science, 797 Changwondaero, Seongsan-gu, \\ Changwon, Gyeongsangnam-do 51508, Korea; adsj1503@kims.re.kr (S.L.); cy916@kims.re.kr (C.Y.L.); \\ jmlee@kims.re.kr (J.L.); sih1654@kims.re.kr (I.-H.S.) \\ 2 School of Materials Science and Engineering, Pusan National University, 2 Busandaehak-ro 63beon-gil, \\ Geumjeong-gu, Busan 46241, Korea \\ * Correspondence: hjhoon@kims.re.kr (J.-H.H.); sehun@pusan.ac.kr (S.-H.K.) \\ + These authors contributed equally to this work.
}

Received: 5 October 2020; Accepted: 16 October 2020; Published: 19 October 2020

\begin{abstract}
Porous ceramics have been extensively investigated because of their high-temperature and chemical stabilities, which are far superior to those of porous polymers and porous metals, despite their mechanical instability. Among various kinds of porous ceramic, reticulated porous ceramics have attracted considerable attention because of their extremely high porosity, which is generally higher than $90 \%$ and can maximize the advantages of this class of materials. However, to the best of our knowledge, sufficient data are not available on the preparation of low-cost, abundant, and natural material-based reticulated porous ceramics. Therefore, we obtained and characterized reticulated porous diatomite-kaolin composites prepared under various processing conditions, such as solid loading, average particle size, and pore density. The experimental data were used to investigate whether the densities and compressive strengths of the reticulated porous diatomite-kaolin composite can be tailored, and to assess the potential of these materials in different application fields.
\end{abstract}

Keywords: reticulated porous diatomite-kaolin composite; pore structure; compressive strength

\section{Introduction}

Porous ceramics have received significant attention in past decades [1] because of their extremely advantageous properties such as high thermal and chemical stability. These properties render the replacement of porous ceramics difficult with alternatives such as porous metals and polymers, thereby facilitating their utilization for different application fields. Among the various kinds of porous ceramic, reticulated porous ceramics are promising candidates for use in various application fields, especially where a high mass transfer and extremely low density are simultaneously required. Reticulated porous ceramics have a net-like pore structure with widely open cells, unlike foams formed by soap bubbles, which consist of fully closed cells.

Reticulated porous ceramics are prepared by coating a reticulated polyurethane foam (as sacrificial polymer template) with a slurry consisting of ceramic particles, which will be the main and only constituent of the final product. Then, the ceramic slurry-coated reticulated polyurethane foam is heat-treated to burn off the reticulated polyurethane foam and finally sinter the coated ceramic particles. Typically, the porosity of reticulated porous ceramics is higher than $90 \%$. Therefore, a highly inter-connected pore structure with high porosity amplifies one of the shortcomings (inherent brittleness) of ceramics. The mechanical instability of reticulated porous ceramics remains a challenging issue for their further application. 
Generally, the mechanical stability of typical porous ceramics depends on both their flexural and compressive strengths. However, it is interesting to observe that the mechanical stability of reticulated porous ceramics is mainly dependent on their compressive strength. For example, although the flexural strength of porous alumina was found to be significantly higher than that of a porous diatomite-kaolin composite [2], the compressive strength of reticulated porous alumina was similar to that of the reticulated porous diatomite-kaolin composite [3]. This discrepancy can be explained by their completely different pore characteristics, which are dependent on the preparation method of the porous ceramics.

Therefore, the compressive strengths of various reticulated porous ceramics are different from those observed when they are prepared as other types of porous ceramics. Typical examples of compressive strengths of reticulated porous ceramics are: $1.60 \mathrm{MPa}$ (prepared from alumina) [4], $1.59 \pm 0.13 \mathrm{Mpa}$ [5] and 1.08 $\pm 0.17 \mathrm{Mpa}$ [6] (silicon carbide), $0.85 \pm 0.13 \mathrm{Mpa}$ (zirconia) [7], $0.62 \pm 0.03 \mathrm{Mpa}$ [8] and $0.73 \mathrm{Mpa}$ [9] (mullite), 1.4 Mpa (aluminum nitride) [10], and $0.47 \pm 0.02 \mathrm{Mpa}$ (cordierite) [11]. On the other hand, the compressive strengths of reticulated porous ceramics are strongly dependent on the pore density (expressed in pores per inch, PPI) and on whether the processing conditions are fully optimized or not.

Interestingly, the above characteristics of reticulated porous ceramics provide an opportunity to use low-cost natural-based materials. If the processing conditions are adequately optimized, the compressive strength of reticulated porous ceramics prepared from low-cost natural-based materials such as clays can match that of ceramics prepared from conventional materials such as alumina and zirconia.

Therefore, we recently, investigated diatomite as a feasible candidate for reticulated porous ceramics, among numerous low-cost natural-based materials. Unlike other materials of this group with plate-like shapes such as pyrophyllite [12], diatomite is uniquely advantageous for preparing porous ceramics. This is due to its porous and irregular shape, which does not require the addition of any kind of pore former or the application of a partial sintering technique. Interestingly, it is much more difficult to prepare a dense diatomite as compared to its counterpart. The strut walls of reticulated porous diatomite are also porous, unlike those of the reticulated porous ceramics, which are typically dense. Hence, the strut walls of reticulated porous diatomite can also play an important role in increasing the overall permeability of the ceramics, unlike the walls of reticulated porous ceramics that act as a barrier to block fluent mass transfer.

Although the nature of diatomite can be used to maximize the advantages of reticulated porous ceramics, overcoming their drawbacks remains challenging. For example, slurry rheology modification [13], dip coating [14], vacuum infiltration coating [15], centrifuge coating [16], multiple slurry coatings [17], and whisker-reinforcement coating [18] methods have been extensively investigated to reduce the shortcomings of reticulated porous ceramics. In addition, we had previously reported that the compressive strength of reticulated porous alumina can be enhanced by optimizing the processing conditions, including the multiple alumina coating layers and the heat treatment temperature [19]. However, the compressive strengths of reticulated porous ceramics cannot be increased to match those of porous ceramics. Therefore, a good approach to maximize the advantages of reticulated porous ceramics involves the use of a low-cost natural-based material such as diatomite.

Various types of porous diatomite-kaolin composites fabricated by different preparation methods have been described in our previous studies [12,20-31] and in those of other research groups [32-36]. However, to the best of our knowledge, only a few have focused on the detailed preparation and characterization of reticulated porous diatomite-kaolin composites, besides our previous report that discussed the feasibility [3]. It should be noted that the mechanical properties of reticulated porous diatomite are too weak to handle the material in a practical context and to withstand heavy loadings in load-bearing applications, which was confirmed by the reports mentioned above. Therefore, the interest in diatomite compounds naturally shifts to diatomite-based composites. 
In a previous report [3], a comparison of experimental data suggested that a reticulated porous diatomite-kaolin composite can be used as a porous dielectric barrier for plasma discharge, with a low density, good dielectric breakdown strength, and acceptable mechanical strength. Moreover, the composite can be prepared from only low-cost natural-based materials such as diatomite and kaolin, at low processing costs, without the aid of a pore former or sintering additive; this is achieved at a relatively low sintering temperature of $1200^{\circ} \mathrm{C}$.

As a follow-up investigation, in this study, we discuss more optimized processing conditions such as the average particle size and the solid loading of the diatomite-kaolin composite slurry; a more detailed characterization of the reticulated porous diatomite-kaolin composites is also presented.

\section{Materials and Methods}

The pore densities of reticulated porous ceramics that can be easily obtained in experiments are generally limited to approximately 45 PPI. Therefore, the studies mentioned above mostly focused on reticulated porous ceramics with pore densities of less than 45 PPI. For example, reticulated porous ceramics prepared from various raw materials such as aluminum nitride (20 PPI) [10], alumina-zirconia composite (20 PPI) [37], alumina (5 PPI [38] and 20 PPI [4,39,40]), zirconia (45 PPI) [7], silicon carbide (8 PPI [5] and 10 PPI [6]), silicon nitride (10 PPI) [18], mullite (20 PPI) [8], and cordierite (10 PPI) [11] had pore density values lower than 45 PPI.

In this study, the target pore density of the reticulated porous diatomite-kaolin composite was 80 PPI. This is because the compressive strength of a reticulated porous diatomite-kaolin composite with pore density of 45 PPI would be too low to enable its application, owing to the inherent porous and irregular nature of diatomite particles, despite being composited with kaolin. As the pore density value exceeds $80 \mathrm{PPI}$, optimizing the viscosity of the ceramic slurry becomes highly important to enable its penetration inside the sacrificial polymer template (a low viscosity being advantageous for this purpose) and completely coat the strut walls of the template (which is facilitated by high viscosity).

The average particle size as well as solid loading, binder, and dispersant are the key properties of slurry compositions that affect the viscosity of a ceramic slurry. Numerous studies have been reported, including on alumina slurries (high solid loading and low viscosity for micro-droplet jetting) [41], alumina magnesia silicate slurries (high solid loading and low viscosity for additive manufacturing) [42], magnesium aluminate spinel slurries (high solid loading and low viscosity for slip casting) [43], zirconia-toughened alumina slurries (high solid loading and low viscosity for additive manufacturing) [44], ceramic ink (appropriate solid loading and suitable viscosity for inkjet printing) [45], and cerium oxide slurries (high solid loading and low viscosity for dip-coating) [46].

In order to prepare a reticulated porous ceramic, a high solid loading and a moderate viscosity are required: (1) if the solid loading of the ceramic slurry is too low, the densification of the strut walls will be insufficient (in other words, the porosity of the strut walls of the reticulated porous ceramic will be too high), resulting in a low compressive strength; (2) if the viscosity of the ceramic slurry is too high, it is difficult for it to completely fill the internal pores of the sacrificial polymer template. It is also very difficult to remove the excessive ceramic slurry while maintaining the formation of thin and uniform ceramic coatings over the strut walls of the sacrificial polymer template; (3) if the viscosity of the ceramic slurry is too low, it will not be sufficient to firmly coat the strut walls of the sacrificial polymer template, as a result, an increasing number of defects can be induced by the uncoated strut wall because of the low adhesion, severely degrading the compressive strength of reticulated porous ceramics.

Generally, the viscosity of the ceramic slurry increased sharply with increasing solid loading and decreased with increasing particle size. Therefore, to obtain a high solid loading diatomite-kaolin composite slurry with moderate viscosity, we tried to identify the optimal composition with the appropriate amount and average size of diatomite-kaolin composite particles. Although a slightly higher solid loading might be achieved by surface modification $[47,48]$, we decided to leave this challenge for a future study. 
The average particle size of the diatomite-kaolin composite was controlled by wet ball-milling using alumina balls (diameter $10 \mathrm{~mm}$, ball to powder ratio $=1: 2$ ) for $0,4,8$, and $24 \mathrm{~h}$. Typical polyurethane foams (SKB Tech, Ulsan, Korea) with pore densities of 45 and 80 PPI along with dimensions of $50 \mathrm{~mm}$ $\times 50 \mathrm{~mm} \times 20 \mathrm{~mm}$ were used as sacrificial templates. A batch of diatomite-kaolin composite slurry was prepared to coat the sacrificial polymer template, and consisted of 50-80 g of diatomite (Celite 499, Celite Corp, Barbara, CA, USA), 15-24 g of kaolin (Kaolin, Sigma-Aldrich, St. Louis, MO, USA) as a strength enhancer, $100 \mathrm{~mL}$ of distilled water as a solvent, $10 \mathrm{~g}$ of polyvinyl alcohol (PVA) as an organic binder (PVA 500, Junsei Chemical, Tokyo, Japan). The mixing ratio of kaolin was set to $30 \mathrm{wt} . \%$ of diatomite. The effect of the kaolin mixing ratio on the properties of the reticulated porous diatomite-kaolin composite will be reported in a separate study.

To uniformly mix the diatomite-kaolin composite with the other additives, the diatomite-kaolin composite slurry was ball-milled again for $4 \mathrm{~h}$ using alumina balls. The reticulated porous diatomite-kaolin composite specimens were prepared by the conventional replica method. A sacrificial polymer template (polyurethane foam) was soaked in the diatomite-kaolin composite slurry until its internal voids, cells, and pores were completely coated with diatomite-kaolin composite particles. Then, the impregnated polyurethane foam was squeezed to remove any excess diatomite-kaolin composite slurry that did not participate in the coating of the strut walls, and to enable the formation of a thin diatomite-kaolin composite coating layer over the struts of the polyurethane foam. After that, the impregnated polyurethane foam was fully dried for $24 \mathrm{~h}$ at $25^{\circ} \mathrm{C}$. Subsequently, the dried specimen was heat-treated at $400^{\circ} \mathrm{C}$ (heating ramp was $5^{\circ} \mathrm{C} / \mathrm{min}$ ) for $1 \mathrm{~h}$ to burn off the organic binder and the sacrificial template, and finally sintered for $1 \mathrm{~h}$ at $1200^{\circ} \mathrm{C}$ (heating ramp was $5^{\circ} \mathrm{C} / \mathrm{min}$ ). After sintering, the polyurethane foam coated with the diatomite-kaolin composite slurry transformed into the reticulated porous diatomite-kaolin composite.

The average particle sizes of diatomite and kaolin were determined by a particle size analyzer (LSTM 13320 MW, Beckman Coulter, Brea, CA, USA). The pore structures and characteristics of the reticulated porous diatomite-kaolin composites were analyzed using scanning electron microscopy (SEM, JSM-5800, JEOL, Tokyo, Japan) and mercury porosimetry (Autopore IV 9510, Micromeritics, Norcross, GA, USA). The viscosity was measured using a rotational rheometer (Discovery HR-1, TA Instruments, New Castle, DE, USA) at $25^{\circ} \mathrm{C}$. The three-dimensional microstructure was investigated by micro-computed tomography (micro-CT, XT H 160, voxel size $=3 \mu \mathrm{m}$, Nikon, Tokyo, Japan). The compressive strengths of the reticulated porous diatomite specimens were measured with a fixture using an Instron 4206 (Instron, Norwood, MA, USA) testing system. Specimens with dimensions of $20 \mathrm{~mm} \times 20 \mathrm{~mm} \times 20 \mathrm{~mm}$ were machined for the compressive strength tests.

\section{Results}

Typical sacrificial polymer templates (in this study, commercial polyurethane foams) with pore densities of 10, 25, 45, 60, and 80 PPI are shown in Figure 1a. Figure 1b shows the as-prepared reticulated porous diatomite-kaolin composite specimens with pore densities of 10 , $25,45,60$, and 80 PPI, which were prepared using the polyurethane foams and diatomite-kaolin composite slurry. The sintering temperature of the reticulated porous diatomite-kaolin composite specimens was determined to be $1200{ }^{\circ} \mathrm{C}$. Based on our previous study and other reports in the literature $[23,24,49,50]$, it is well known that the reticulated porous diatomite-kaolin composite maintains a similar microstructure up to $120{ }^{\circ} \mathrm{C}$ after that it begins to melt because of impurities such as $\mathrm{Na} 2 \mathrm{O}, \mathrm{K} 2 \mathrm{O}, \mathrm{Al} 2 \mathrm{O} 3, \mathrm{CaO}$ and $\mathrm{MgO}$ [50], which can damage the characteristic porous morphology of diatomite particles. 


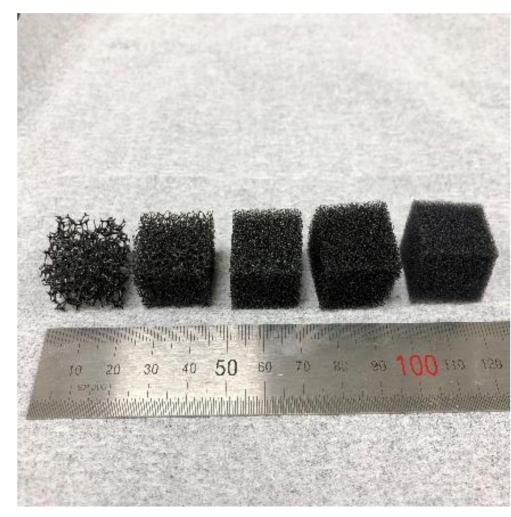

(a)

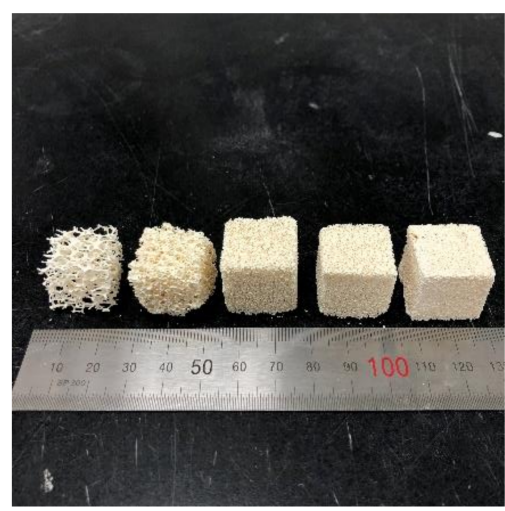

(b)

Figure 1. Optical images of (a) sacrificial polymer templates (in this study, polyurethane foam) with pore densities of 10, 25, 45, 60, and 80 pores per inch (PPI, from left to right), used in a typical replica method. (b) Reticulated porous diatomite-kaolin composite specimens with pore densities of 10, 25, 45, 60 , and 80 PPI (from left to right).

To control the average particle size of diatomite particles, ball-milling was carried out for 0 , 4,8 , and $24 \mathrm{~h}$. Typical scanning electron microscopy (SEM) images of diatomite particles after the corresponding ball-milling processes are shown in Figure $2 \mathrm{a}-\mathrm{d}$, respectively. Obviously, the average particle sizes of diatomite decreased as the ball milling time increased, until a certain saturation point was reached. The particle size distributions of diatomite samples after being ball milled for $0,4,8$, and $24 \mathrm{~h}$ are shown in Figure 2e, and the corresponding average particle sizes were 12.79, 10.54, 8.77, and $8.36 \mu \mathrm{m}$, respectively. The diatomite particles were also ball milled for 1 and $2 \mathrm{~h}$ (with corresponding average particle size of 11.66 and $11.11 \mu \mathrm{m}$, respectively); however, because of the negligible particle size difference, further experiments were carried out using only diatomite particles ball milled for $0,4,8$, and $24 \mathrm{~h}$.

It is well known that reticulated porous diatomite is too weak to handle, owing to the high porosity of the reticulated porous ceramic and the inherent porous nature of diatomite particles $[20,21,23]$. Therefore, to the best of our knowledge, only a few applications of reticulated porous diatomite prepared by the replica method have been reported. To expand the application fields of reticulated porous diatomite beyond its typical applications (porous diatomite filters prepared by the extrusion method and porous diatomite foot mats prepared by slip casting), we introduced kaolin to form a diatomite-kaolin composite and determined the optimal processing conditions to obtain the maximum compressive strength while maintaining the advantageous properties of diatomite.

The average particle size of the as-received kaolin $(1.53 \mu \mathrm{m})$ was approximately $12 \%$ that of the as-received diatomite $(12.79 \mu \mathrm{m})$. Therefore, we suggested that the plate-like kaolin particles could strengthen the coarsely and partially inter-connected pore channels generated by diatomite particles [24]. It should also be mentioned that the pore structure characterization of a reticulated porous ceramic should be based on the results of several complementary techniques such as (1) SEM, (2) micro-CT, and (3) mercury porosimetry [51].

Typical fractured strut walls of the sacrificial polymer template (a commercial polyurethane foam) and of the reticulated porous diatomite-kaolin composite are shown in Figure 3a,b, respectively. The macroscale voids generated after the pyrolysis of the polymer template (during the burn-out process in the replica method), shown in Figure $3 b$, are common features that strongly affect the overall mechanical properties. It is well known that these inevitable macroscale voids and defects make any kind of reticulated porous ceramics prone to external load bearings, and significantly reduce their application potential. If the cross-section of the strut walls of the sacrificial polymer template is circular, unlike the triangular shape of the commercial polymer template in Figure 3a, it can improve the mechanical properties of reticulated porous ceramics [52]. Strut walls with a circular cross-section 
of the sacrificial polymer template can be prepared by three-dimensional (3D) printing techniques associated with computer-aided design (CAD) software. Because adopting an expensive 3D printing technique would be inconsistent with the aim of introducing a low-cost, natural-based diatomite-kaolin material into a reticulated porous ceramic, in this study we focused on the optimization of processing conditions such as solid loading, average particle size, and pore density.

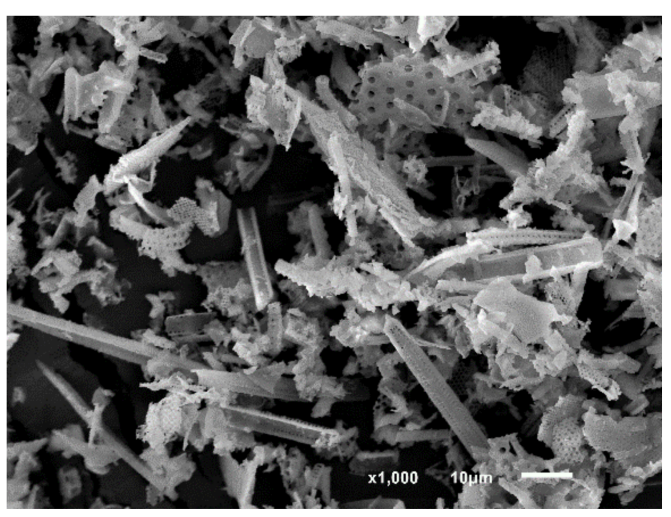

(a)

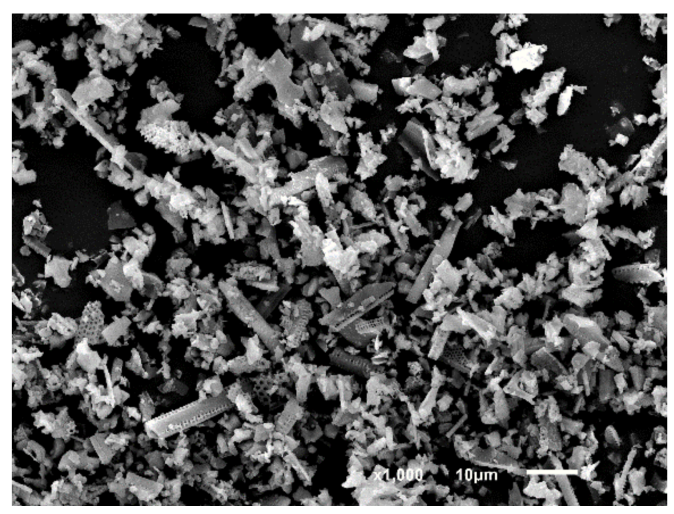

(c)

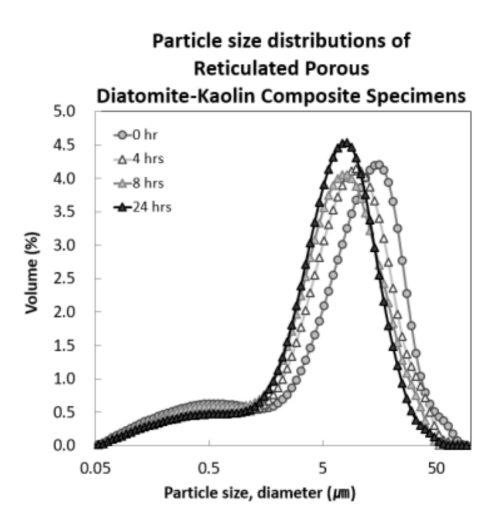

(e)

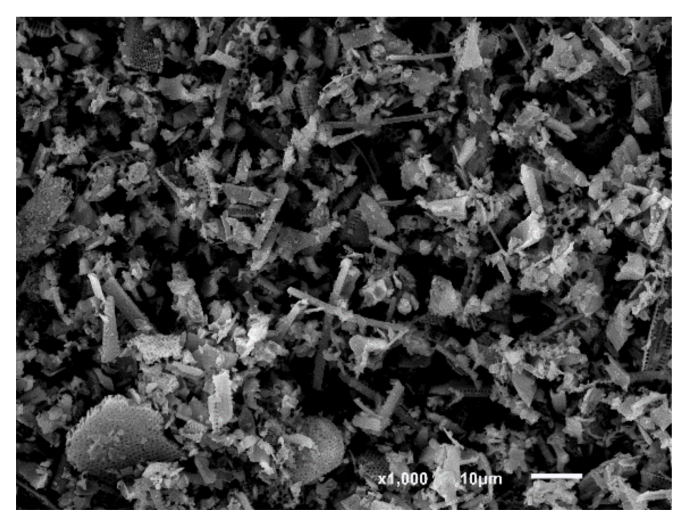

(b)

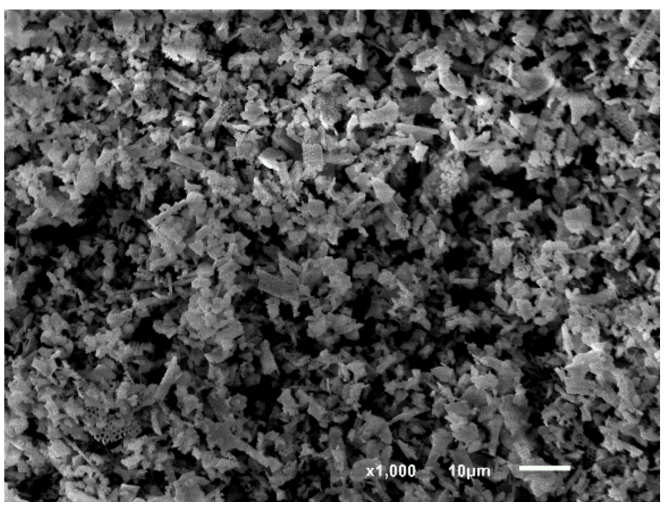

(d)

Figure 2. Scanning electron microscopy (SEM) images of diatomite particles ball milled for (a) $0 \mathrm{~h}$ (as-received), (b) $4 \mathrm{~h}$, (c) $8 \mathrm{~h}$, and (d) $24 \mathrm{~h}$; (e) particle size distributions of diatomite particles ball-milled for $0,4,8$, and $24 \mathrm{~h}$. 


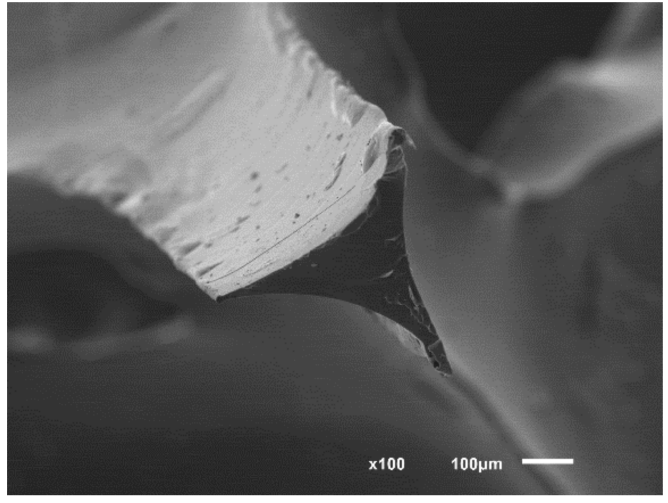

(a)

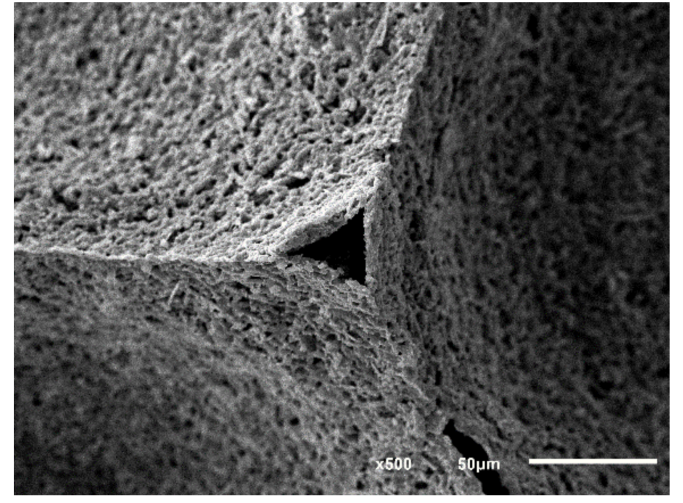

(b)

Figure 3. SEM images of a fractured strut wall of (a) the sacrificial polymer template and (b) the reticulated porous diatomite-kaolin composite.

Moreover, it is reasonable that the porous and irregular nature of the strut walls of a reticulated porous diatomite-kaolin composite would severely reduce the compressive strength. Therefore, it is interesting to investigate whether the more refined strut walls (obtained by increasing the solid loading and reducing the average particle size of the diatomite-kaolin composite slurry) of the reticulated porous diatomite-kaolin composite can enhance the compressive strength. This aspect will be discussed later.

It is difficult to judge whether a reticulated porous diatomite-kaolin composite specimen has been prepared successfully or not. It is important to determine whether the density would contribute to the overall strength (when the diatomite-kaolin composite slurry is properly coated on the strut walls of the sacrificial polymer template) or not (when the slurry is distributed non-uniformly as debris located deep inside the reticulated porous ceramic specimen). Therefore, in this study, non-destructive micro-CT analysis was used to investigate the reticulated porous ceramic specimens.

Figure 4a shows the three-dimensional microstructure of a typical reticulated porous diatomite-kaolin composite specimen (pore density $=45 \mathrm{PPI}$ ), reconstructed by micro-CT. A representative cross-section from the micro-CT reconstructions of the specimen is shown in Figure $4 \mathrm{~b}$. The image clearly shows that the reticulated porous diatomite-kaolin composite had well-defined inter-connected pore channels, as intended. Moreover, the figure does not show any evidence of voids or of a non-uniform distribution of strut walls inside the composite, which would be frequently observed when using the un-optimized ceramic slurry in the preparation.

Figure $4 \mathrm{c}$ shows the three-dimensional microstructure of a typical reticulated porous diatomite-kaolin composite specimen (pore density $=80 \mathrm{PPI}$ ), reconstructed by micro-CT. A representative cross-section from the micro-CT reconstruction of the specimen is shown in Figure $4 \mathrm{~d}$. The image clearly shows that the reticulated porous diatomite-kaolin composite had a well-defined inter-connected pore structure, similar to the sample with a pore density of 45 PPI. The pore channels beneath the surface were not substantially blocked, which shows the effectiveness of the diatomite-kaolin composite slurry that had penetrated deep inside the sacrificial polymer template. Moreover, the presence of the blocked pore channels is not a key factor, unlike in conventional reticulated porous ceramics, because the residual diatomite-kaolin particles cannot actually block the pore channels (even if they were intended to) owing to their porous and irregular nature. Generally, when the pore density of the sacrificial polymer template reaches approximately $60 \mathrm{PPI}$, the processing window of a ceramic slurry composition (in terms of parameters such as solid loading and viscosity) becomes narrow. 


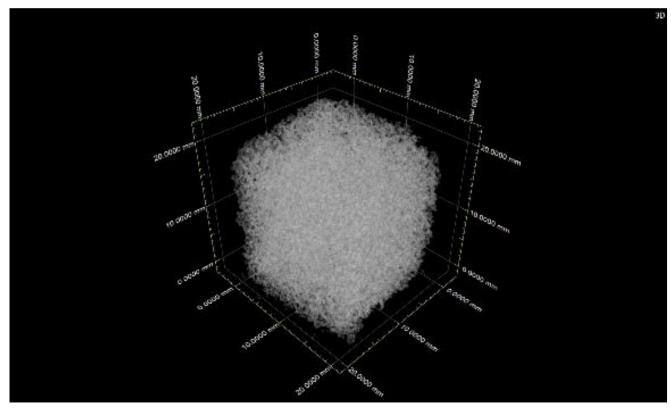

(a)

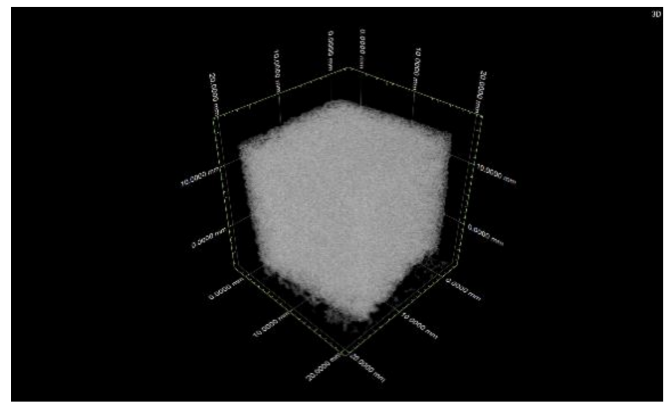

(c)

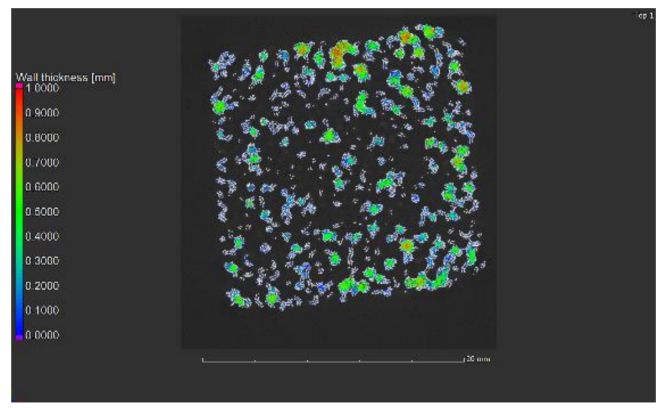

(b)

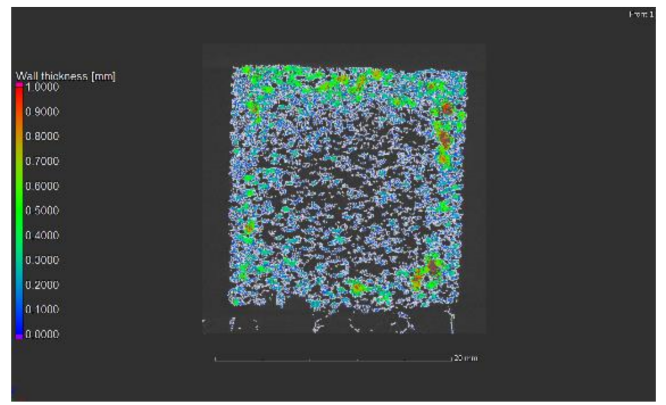

(d)

Figure 4. (a) 3D microstructure of typical reticulated porous diatomite-kaolin composite with a pore density of $45 \mathrm{PPI}$, reconstructed by micro-computed tomography (micro-CT). (b) Representative slice extracted from the micro-CT reconstructions. (c) 3D microstructure of typical reticulated porous diatomite-kaolin composite with a pore density of 80 PPI, reconstructed by micro-CT. (d) Representative slice extracted from the micro-CT reconstructions.

Figure 5 shows the pore size distributions of the reticulated porous diatomite-kaolin composite specimens (pore density $=45 \mathrm{PPI}$ ), prepared from the composite particles ball milled for $0,4,8$, and $24 \mathrm{~h}$. As the ball-milling times increased, the pore size and pore volume fraction of the reticulated porous diatomite-kaolin composite specimens showed a slight decrease. Because the number of strut walls is fixed (it only depends on the pore density of the sacrificial polymer template), any difference in the pore size distributions can only be ascribed to the different ball milling times, resulting in diatomite-kaolin composite particles with different amounts of internal pores and average sizes.

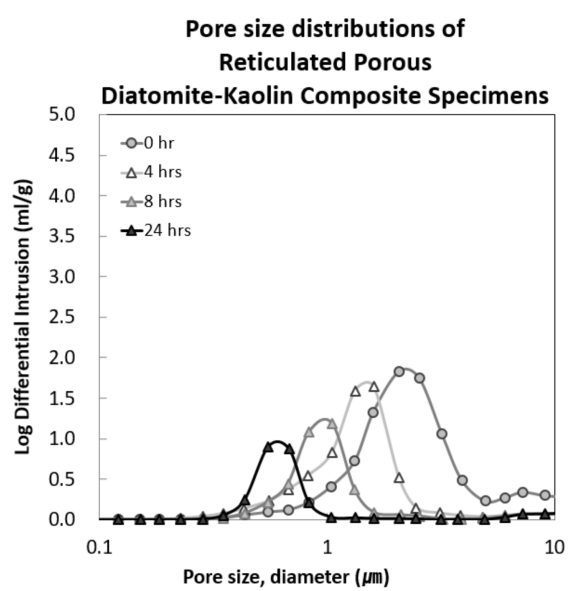

Figure 5. Pore size distributions of reticulated porous diatomite-kaolin composites prepared from diatomite-kaolin composite particles ball milled for $0,4,8$, and $24 \mathrm{~h}$. 
In Figure 5, the pore size distributions of the reticulated porous diatomite-kaolin composite specimens covered the range from 0.5 to $5 \mu \mathrm{m}$, which reflects the pore size distribution of the strut walls. The size of the voids generated by the burn-out sacrificial polymer template ranged from 50 to $100 \mu \mathrm{m}$, whereas that of the large cell composed by the strut walls was in the sub-millimeter range.

Figure 6a shows a viscosity vs. shear rate plot of the diatomite-kaolin composite slurries prepared with different ball milling times at a solid loading of $50 \mathrm{wt} . \%$. Upon comparing the viscosity of the diatomite-kaolin composite slurry ball milled for $24 \mathrm{~h}$ to those of the samples ball milled for 0,4 , and $8 \mathrm{~h}$, it was observed that the viscosities of the slurries were affected more strongly by the solid loading. For a solid loading of $50 \mathrm{wt} . \%$, although the viscosities did not increase significantly as the ball milling time increased from 0 to $8 \mathrm{~h}$, a drastic increase was observed at a critical point ( $24 \mathrm{~h}$ under these conditions). However, Figure $6 \mathrm{~b}$ shows that the viscosities increased as the ball milling time was increased from 0 to $24 \mathrm{~h}$; this can be understood by assuming that, until the solid loading reaches a certain point, the effect of the particle size decrease is marginal. In addition, the viscosities were still found to be significantly low, implying that the slurry may penetrate more easily the excessively narrow cells of a sacrificial polymer template with a pore density greater than 45 PPI. These correlations are in good agreement with established literature data [13].

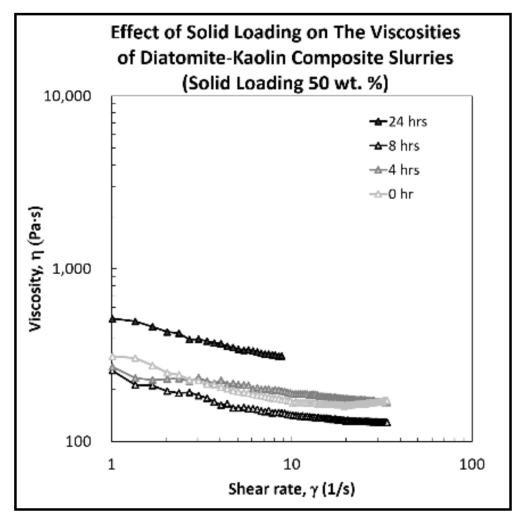

(a)

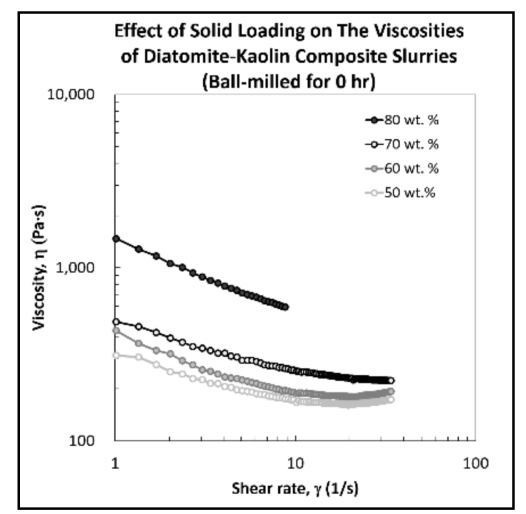

(c)

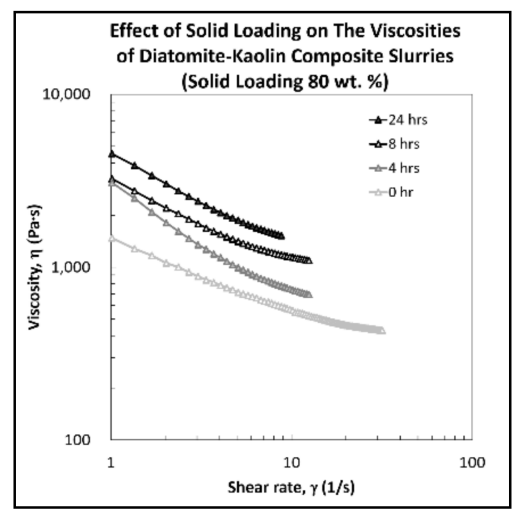

(b)

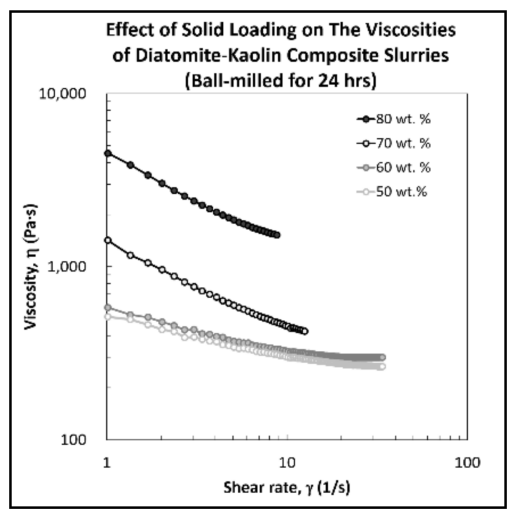

(d)

Figure 6. Viscosities of diatomite-kaolin composite slurries used for the preparation of reticulated porous diatomite-kaolin composite: ball milled for $0,4,8$, and $24 \mathrm{~h}$ at a solid loading of (a) $50 \mathrm{wt}$. $\%$, (b) $80 \mathrm{wt} . \%$, (c) ball milled for $0 \mathrm{~h}$ at solid loadings ranging from 50 to $80 \mathrm{wt} . \%$, (d) ball milled for $24 \mathrm{~h}$ at solid loadings ranging from 50 to $80 \mathrm{wt} . \%$.

For comparison, Figure $6 \mathrm{c}$ display a viscosity vs. shear rate plot of diatomite-kaolin composite slurries ball milled for $0 \mathrm{~h}$ with different solid loadings. The viscosity of slurries ball-milled for $0 \mathrm{~h}$ with solid loadings from 50 to $80 \mathrm{wt}$.\% (Figure 6c) were then compared to those of slurries ball 
milled for $24 \mathrm{~h}$ with solid loadings from 50 to $80 \mathrm{wt} . \%$ (Figure $6 \mathrm{~d}$ ), The comparison shows that at the same solid loading, the viscosities of the diatomite-kaolin composite slurries ball milled for $24 \mathrm{~h}$ were higher, because of the average particle size of the diatomite-kaolin composite (which is directly related to their surface area). As the viscosity of a diatomite-kaolin composite slurry can be tailored easily with the aid of an appropriate surfactant, the absolute value of the viscosity may not be very meaningful. Therefore, we investigated the effect of processing conditions such as solid loading, pore density, and average particle size on the mechanical strengths and densities of the reticulated porous diatomite-kaolin composites.

As discussed above, if the viscosity of a diatomite-kaolin composite slurry is too high, it is difficult for the slurry to completely fill the internal pores of a sacrificial polymer template. It is also very difficult to remove the excess diatomite-kaolin composite slurry while maintaining the formation of a thin and uniform ceramic coatings over the strut walls of the sacrificial polymer template. Therefore, we estimated that the conditions corresponding to the maximum viscosity ( $24 \mathrm{~h}$ ball milling of the diatomite-kaolin composite slurry with $80 \mathrm{wt} . \%$ solid loading) would not yield the highest compressive strength.

To confirm the above hypothesis, we systematically measured the densities and compressive strengths of the diatomite-kaolin composite specimens. Figure 7a shows the densities of the reticulated porous diatomite-kaolin composite specimens prepared with different solid loadings (from 50 to $80 \mathrm{wt} . \%$ ) and ball-milling times (from 0 to $24 \mathrm{~h}$ ), which had a pore density of 45 PPI. As the solid loading amount or ball milling time increased, the densities of the specimens showed a corresponding increase. This shows that if the pore density is low enough, the increased viscosity can result in a linear increase in the applied mass (the diatomite-kaolin composite slurry), regardless of the compressive strength.

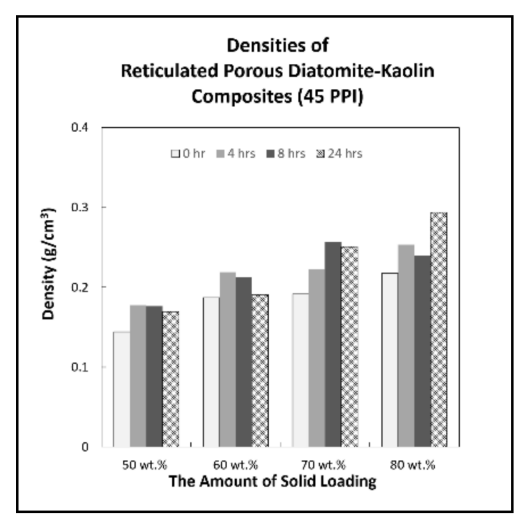

(a)

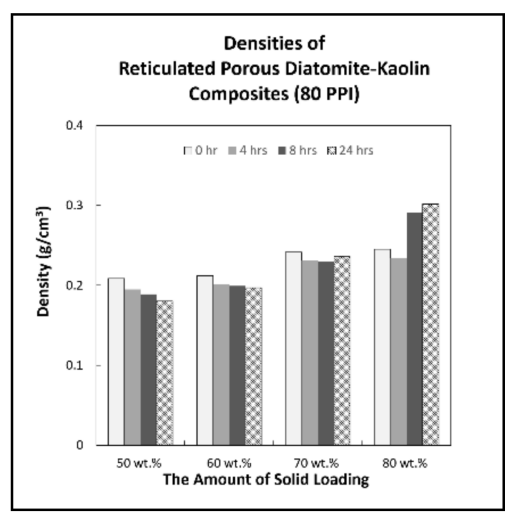

(b)

Figure 7. Densities of reticulated porous diatomite-kaolin composites prepared from the composite particles ball milled for $0,4,8$, and $24 \mathrm{~h}$, at solid loadings ranging from 50 to $80 \mathrm{wt}$. $\%$, with pore densities of (a) 45 PPI and (b) 80 PPI.

Figure $7 \mathrm{~b}$ shows the densities of the reticulated porous diatomite-kaolin composite specimens with 80 PPI pore density, prepared with different solid loadings (from 50 to $80 \mathrm{wt} . \%$ ) and ball-milling times (from 0 to $24 \mathrm{~h}$ ). Unlike the samples with a pore density of 45 PPI in Figure 7a, as the ball-milling time reached $24 \mathrm{~h}$, the densities of the specimens decreased. This suggests that it is difficult for the internal pores of the sacrificial polymer template to be completely filled with the highly viscous diatomite-kaolin composite slurry ball milled for $24 \mathrm{~h}$.

Figure 8a shows the compressive strengths of the reticulated porous diatomite-kaolin composite specimens with a pore density of $45 \mathrm{PPI}$, prepared with different solid loadings (from 50 to $80 \mathrm{wt} . \%$ ) and ball-milling times (from 0 to $24 \mathrm{~h}$ ). Similar to the trend of the densities, when the solid loading amount or ball-milling time increased, the compressive strengths of the specimens showed a corresponding increase. It was thus inferred that when the pore density was 45 PPI, the density could contribute 
to the compressive strength of the specimens. The compressive strengths of the reticulated porous diatomite-kaolin composite specimens with different solid loadings (50 to $80 \mathrm{wt} . \%$ ) and ball-milling times $(0$ to $24 \mathrm{~h}$ ), which had a pore density of 80 PPI, are shown in Figure 8b. Similar to the trend of the densities, when the ball milling time reached $24 \mathrm{~h}$, the compressive strength of the specimen decreased. This suggests that when the pore density was 80 PPI, the density increases did not fully contribute to the compressive strength of the specimens.

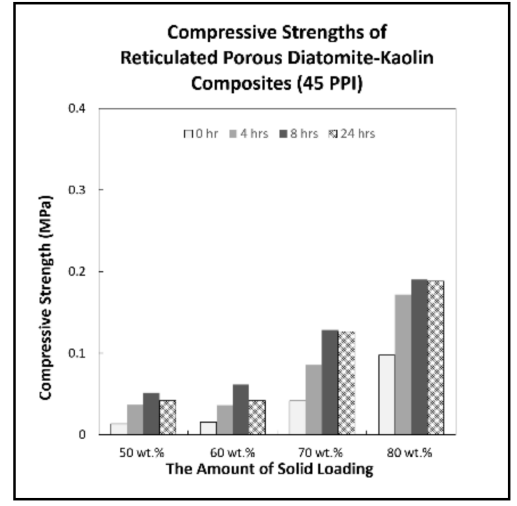

(a)

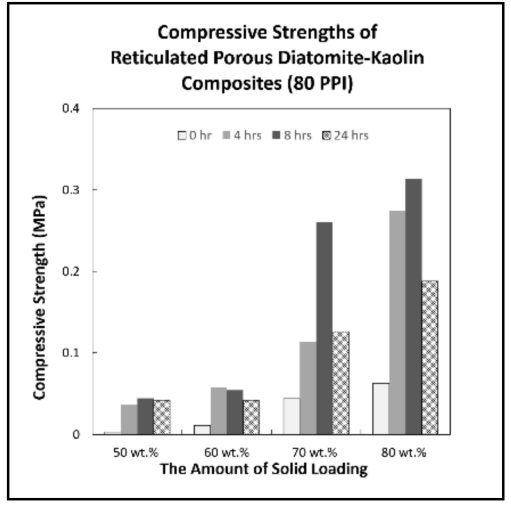

(b)

Figure 8. Compressive strengths of reticulated porous diatomite-kaolin composites that were prepared from composite particles ball milled for $0,4,8$, and $24 \mathrm{~h}$, at solid loadings ranging from 50 to $80 \mathrm{wt}$. $\%$, with pore densities of (a) 45 PPI and (b) 80 PPI.

In our previous report [3], we discussed the whether a reticulated porous diatomite-kaolin composite can be used as a low-cost and low-density dielectric barrier or insulator. As a follow-up study, here, we investigated whether the compressive strength of a reticulated porous diatomite-kaolin composite can be enhanced by tailoring processing conditions such as the solid loading and average particle size of the diatomite-kaolin composite slurry. Considering that the compressive strength of typical reticulated porous alumina samples with compressive strength higher than $1.0 \mathrm{MPa}$, the compressive strength of the reticulated porous diatomite-kaolin composite is acceptable; therefore, the present composite can employed as an alternative to conventional reticulated porous ceramics in various application fields, except for those involving hard loading conditions.

\section{Conclusions}

Reticulated porous diatomite-kaolin composite specimens were prepared by a conventional replica method using sacrificial polymer templates. The effects of the parameters of the diatomite-kaolin composite slurry (such as solid loading and average particle size) on the densities and compressive strengths of the reticulated porous diatomite-kaolin composites were investigated. The results highlighted the following relationships between the properties of the reticulated porous diatomite-kaolin composite and the processing conditions:

(1) At 45 PPI pore density, the increase in solid loading and the decrease in average particle size of the diatomite-kaolin composite slurry fully contributed to the increase in density of the reticulated porous diatomite-kaolin composite; accordingly, the compressive strength increased. We inferred that the pore density of the sacrificial polymer template (45 PPI) was low enough to ensure the coating of the strut walls and the removal of the residual diatomite-kaolin composite particles, and did not have a significant effect even under the conditions corresponding to the highest viscosity (50 wt.\% solid loading and ball-milling for $24 \mathrm{~h}$ ).

(2) At 80 PPI pore density, the increase in solid loading and decrease in average particle size of the diatomite-kaolin composite slurry did not always affect the increase in density of the reticulated 
porous diatomite-kaolin composite, and the compressive strength peaked at a specific point (50 wt.\% solid loading and ball milling for $8 \mathrm{~h}$ ). This suggested that the pore density of the sacrificial polymer template (80 PPI) was too high to penetrate inside the sacrificial polymer template and to completely remove the residual diatomite-kaolin composite particles, and had a significant effect until the viscosity reached the value corresponding to $50 \mathrm{wt} . \%$ solid loading and ball milling for $8 \mathrm{~h}$.

(3) The pore density of practical and easily obtained reticulated porous ceramics can be extended to 80 PPI, by using a diatomite-kaolin composite and applying appropriate processing conditions.

Because of the porous and irregular morphology of the diatomite-kaolin composite particles and inherent advantages such as low cost, abundance, and natural origin, it is important to investigate the potential of the reticulated porous diatomite-kaolin composites. The compressive strength of a reticulated porous diatomite-kaolin composite can be enhanced to an acceptable level by tailoring processing conditions such as solid loading, average particle size, and pore density; then, the composite can be employed in a similar way to conventional reticulated porous ceramics in various application fields, except those involving hard-loading conditions.

Author Contributions: J.-H.H. and S.-H.K. conceived and designed the experiments; S.L. and C.Y.L. performed the experiments; J.L. and J.-H.H. analyzed the data; I.-H.S. contributed reagents/materials/analysis tools; S.L. wrote the paper. All authors have read and agreed to the published version of the manuscript.

Funding: This research was funded by Fundamental Research Program of the Korean Institute of Materials Science (KIMS), Grant No. PNK6780, and by the Technology Innovation Program (20003782) of the Ministry of Trade, Industry and Energy.

Acknowledgments: This study was supported financially by Fundamental Research Program of the Korean Institute of Materials Science (KIMS), Grant No. PNK6780, and by the Technology Innovation Program (20003782) of the Ministry of Trade, Industry and Energy.

Conflicts of Interest: The authors declare no conflict of interest.

\section{References}

1. Studart, A.R.; Gonzenbach, U.T.; Tervoort, E.; Gauckler, L.J. Processing Routes to Macroporous Ceramics: A Review. J. Am. Ceram. Soc. 2006, 89, 1771-1789. [CrossRef]

2. Ha, J.H.; Bukhari, S.Z.A.; Lee, J.; Song, I.H. Preparation and characterisation of aluminabased composite support layers. Adv. Appl. Ceram. 2016, 115, 229-235. [CrossRef]

3. Lee, S.; Ha, J.H.; Lee, J.; Song, I.H.; Kwon, S.H. Preparation and Characterization of a Low-Cost and Natural Material-Based Reticulated Porous Diatomite-Kaolin Composite. Appl. Sci. 2020, 10, 2125. [CrossRef]

4. Rannabauer, S.; Söffker, G.M.; Scheunemann, M.; Betke, U.; Scheffler, M. Increased Mechanical Stability and Thermal Conductivity of Alumina Reticulated Porous Ceramics (RPC) by Nanoparticle Infiltration Processing. Adv. Eng. Mater. 2017, 19. [CrossRef]

5. Yao, X.; Tan, S.; Huang, Z.; Jiang, D. Effect of recoating slurry viscosity on the properties of reticulated porous silicon carbide ceramics. Ceram. Int. 2006, 32, 137-142. [CrossRef]

6. Liang, X.; Li, Y.; Sang, S.; Xu, Y.; Chen, Y.; Li, B.; Aneziris, C. Enhanced mechanical properties of SiC reticulated porous ceramics via adjustment of residual stress within the strut. Int. J. Appl. Ceram. Technol. 2018, 15, 28-35. [CrossRef]

7. Jun, I.K.; Koh, Y.H.; Song, J.H.; Lee, S.H.; Kim, H.E. Improved compressive strength of reticulated porous zirconia using carbon coated polymeric sponge as novel template. Mater. Lett. 2006, 60, 2507-2510. [CrossRef]

8. Akpinar, S.; Altun, I.A.; Onel, K. Effects of $\mathrm{SiC}$ addition on the structure and properties of reticulated porous mullite ceramics. J. Eur. Ceram. Soc. 2010, 30, 2727-2734. [CrossRef]

9. Liang, X.; Li, Y.; Pan, L.; Sang, S.; Zhu, T.; Li, B.; Aneziris, C.G. Preparation and enhancement of mullite reticulated porous ceramics for porous media combustion. Ceram. Int. 2019, 45, 22226-22232. [CrossRef]

10. Betke, U.; Lieb, A.; Scheffler, F.; Scheffler, M. Manufacturing of Reticulated Open-Cellular Aluminum Nitride Ceramic Foams from Aqueous AlN Suspensions. Adv. Eng. Mater. 2016, 19, 1600660. [CrossRef] 
11. Biswas, P.; Varaprasad, K.; Ramavath, P.; Suresh, M.B.; Khanra, A.K.; Johnson, R. Development of Cordierite Based Reticulated Foams with Improved Mechanical Properties for Porous Burner Applications. Trans. Indian Ceram. Soc. 2017, 76, 56-61. [CrossRef]

12. Ha, J.H.; Lee, S.; Abbas Bukhari, S.Z.; Lee, J.; Song, I.H. The preparation and characterization of alumina-coated pyrophyllite-diatomite composite support layers. Ceram. Int. 2017, 43, 1536-1542. [CrossRef]

13. Voigt, C.; Aneziris, C.G.; Hubálková, J. Rheological Characterization of Slurries for the Preparation of Alumina Foams via Replica Technique. J. Am. Ceram. Soc. 2015, 98, 1460-1463. [CrossRef]

14. Touzin, M.; Béclin, F. Fabrication and characterization of composite sol-gel coatings on porous ceramic substrate. J. Eur. Ceram. Soc. 2011, 31, 1661-1667. [CrossRef]

15. Liang, X.; Li, Y.; Liu, J.; Sang, S.; Chen, Y.; Li, B.; Aneziris, C.G. Improvement of the mechanical properties of $\mathrm{SiC}$ reticulated porous ceramics with optimized three-layered struts for porous media combustion. Ceram. Int. 2017, 43, 3741-3747. [CrossRef]

16. Pu, X.; Liu, X.; Qiu, F.; Huang, L. Novel method to optimize the structure of reticulated porous ceramics. J. Am. Ceram. Soc. 2004, 87, 1392-1394. [CrossRef]

17. Zhu, X.; Jiang, D.; Tan, S.; Zhang, Z. Improvement in the Strut Thickness of Reticulated Porous Ceramics. J. Am. Ceram. Soc. 2001, 84, 1654-1656. [CrossRef]

18. Yue, H.; Wang, X.; Tian, J. Fabrication of $\mathrm{Si}_{3} \mathrm{~N}_{4}$ reticulated porous ceramics reinforced by needle-like $\beta-\mathrm{Si}_{3} \mathrm{~N}_{4}$. Ceram. Int. 2014, 40, 8525-8532. [CrossRef]

19. Ha, J.H.; Lee, S.; Choi, J.R.; Lee, J.; Song, I.H.; Chung, T.J. A cobalt-coated reticulated porous alumina for radar-absorption applications. J. Aust. Ceram. Soc. 2019, 55, 883-891. [CrossRef]

20. Ha, J.H.; Oh, E.; Ahmad, R.; Song, I.H. The effects of pore structures on the air permeation properties of sintered diatomite. Ceram. Int. 2013, 39, 3881-3884. [CrossRef]

21. Ha, J.H.; Oh, E.; Song, I.H. The effect of sacrificial templates on the pore characteristics of sintered diatomite membranes. J. Ceram. Soc. Jpn. 2013, 121, 940-945. [CrossRef]

22. Ha, J.H.; Oh, E.; Song, I.H. The use of a diatomite-kaolin composite coating to design the pore characteristics of a sintered diatomite membrane. Ceram. Int. 2014, 40, 2221-2227. [CrossRef]

23. Ha, J.H.; Oh, E.; Song, I.H. The fabrication and characterization of sintered diatomite for potential microfiltration applications. Ceram. Int. 2013, 39, 7641-7648. [CrossRef]

24. Ha, J.H.; Oh, E.; Bae, B.; Song, I.H. The effect of kaolin addition on the characteristics of a sintered diatomite composite support layer for potential microfiltration applications. Ceram. Int. 2013, 39, 8955-8962. [CrossRef]

25. Ha, J.H.; Lee, J.; Song, I.H.; Lee, S.H. The effects of diatomite addition on the pore characteristics of a pyrophyllite support layer. Ceram. Int. 2015, 41, 9542-9548. [CrossRef]

26. Ha, J.H.; Bae, B.; Song, I.H. Effect of pore characteristics on permeability of sintered diatomite filter for microfiltration. Adv. Appl. Ceram. 2015, 114, 156-163. [CrossRef]

27. Ha, J.H.; Park, Y.H.; Song, I.H. The preparation and pore characteristics of an alumina coating on a diatomite-kaolin composite support layer. J. Ceram. Soc. Jpn. 2014, 122, 714-718. [CrossRef]

28. Ha, J.H.; Jung, D.W.; Song, I.H. The effect of an alumina coating on the pore characteristics of a diatomite-kaolin composite support layer. Ceram. Int. 2014, 40, 12961-12967. [CrossRef]

29. Ha, J.H.; Park, Y.H.; Song, I.H. Alumina coating to realize desired pore characteristics of sintered diatomite membrane. Arch. Met. Mater. 2015, 60, 1175-1178. [CrossRef]

30. Ha, J.H.; Bukhari, S.Z.A.; Lee, J.; Song, I.H.; Lee, S.H. The preparation and characterizations of pyrophyllite-diatomite composite support layers. J. Ceram. Soc. Jpn. 2015, 123, 1043-1050. [CrossRef]

31. Ha, J.H.; Oh, E.; Ahmad, R.; Song, I.H. A particle-stabilized diatomite foam with a bimodal pore structure. J. Ceram. Soc. Jpn. 2013, 121, 426-429. [CrossRef]

32. Šaponjić, A.; Stanković, M.; Majstorović, J.; Matović, B.; Ilić, S.; Egelja, A.; Kokunešoski, M. Porous ceramic monoliths based on diatomite. Ceram. Int. 2015, 41, 9745-9752. [CrossRef]

33. Shen, W.; Feng, L.; Lei, A.; Liu, Z.; Chen, Y. Effects of porosity and pore size on the properties of AgO-decorated porous diatomite ceramic composites. Ceram. Int. 2014, 40, 1495-1502. [CrossRef]

34. Van Garderen, N.; Graule, T.; Aneziris, C.G.; Clemens, F.J. Comparison methods for microstructure analysis on highly porous extrudates based on diatomite filter aids. Microporous Mesoporous Mater. 2013, 171, $215-222$. [CrossRef] 
35. Van Garderen, N.; Clemens, F.J.; Kaufmann, J.; Urbanek, M.; Binkowski, M.; Graule, T.; Aneziris, C.G. Pore analyses of highly porous diatomite and clay based materials for fluidized bed reactors. Microporous Mesoporous Mater. 2012, 151, 255-263. [CrossRef]

36. Vasconcelos, P.V.; Labrincha, J.A.; Ferreira, J.M.F. Permeability of diatomite layers processed by different colloidal techniques. J. Eur. Ceram. Soc. 2000, 20, 201-207. [CrossRef]

37. Chen, R.; Jia, W.; Wang, Y.; Lao, D.; Hei, D.; Li, S. Optimization of the microstructure and properties of $\mathrm{Al}_{2} \mathrm{O}_{3}-\mathrm{ZrO}_{2}$ reticulated porous ceramics via in-situ synthesis of mullite whiskers and flowing-liquid phase. Mater. Lett. 2019, 243, 66-68. [CrossRef]

38. Banerjee, A.; Bala Chandran, R.; Davidson, J.H. Experimental investigation of a reticulated porous alumina heat exchanger for high temperature gas heat recovery. Appl. Therm. Eng. 2015, 75, 889-895. [CrossRef]

39. Voigt, C.; Zienert, T.; Schubert, P.; Aneziris, C.G.; Hubálková, J. Reticulated porous foam ceramics with different surface chemistries. J. Am. Ceram. Soc. 2014, 97, 2046-2053. [CrossRef]

40. Voigt, C.; Jäckel, E.; Aneziris, C.G.; Hubálková, J. Investigations of reticulated porous alumina foam ceramics based on different coating techniques with the aid of $\mu \mathrm{CT}$ and statistical characteristics. Ceram. Int. 2013, 39, 2415-2422. [CrossRef]

41. Cai, J.; Fan, S.; Liu, F.; Jiang, W.; Wu, H.; Fan, Z. Preparation of porous $\mathrm{Al}_{2} \mathrm{O}_{3}$ ceramic microspheres by a novel micro-droplet jetting rapid forming method. Ceram. Int. 2019, 45, 20583-20588. [CrossRef]

42. Chen, Z.; Li, J.; Liu, C.; Liu, Y.; Zhu, J.; Lao, C. Preparation of high solid loading and low viscosity ceramic slurries for photopolymerization-based 3D printing. Ceram. Int. 2019, 45, 11549-11557. [CrossRef]

43. Shafeiey, A.; Enayati, M.H.; Al-Haji, A. The effect of slip casting parameters on the green density of $\mathrm{MgAl}_{2} \mathrm{O}_{4}$ spinel. Ceram. Int. 2017, 43, 6069-6074. [CrossRef]

44. Xing, H.; Zou, B.; Liu, X.; Wang, X.; Chen, Q.; Fu, X.; Li, Y. Effect of particle size distribution on the preparation of ZTA ceramic paste applying for stereolithography 3D printing. Powder Technol. 2020, 359, 314-322. [CrossRef]

45. Güngör, G.L.; Kara, A.; Gardini, D.; Blosi, M.; Dondi, M.; Zanelli, C. Ink-jet printability of aqueous ceramic inks for digital decoration of ceramic tiles. Dyes Pigm. 2016, 127, 148-154. [CrossRef]

46. Balzarotti, R.; Cristiani, C.; Latorrata, S.; Migliavacca, A. Washcoating of low surface area cerium oxide on complex geometry substrates. Part. Sci. Technol. 2016, 34, 184-193. [CrossRef]

47. Liu, W.; Jin, L.; Wang, S. Preparation of transparent $\mathrm{Y}_{2} \mathrm{O}_{3}$ ceramic via gel casting: Realization of high solid volume via surface modification. J. Am. Ceram. Soc. 2019, 102, 6414-6421. [CrossRef]

48. Gao, X.; Wang, R.; Zhao, J.; Huang, J.; Gao, Y.; Liu, H. Influence of surface oxide layer of SiC powder on the rheological properties of its slurry. Int. J. Appl. Ceram. Technol. 2020, 17, 484-490. [CrossRef]

49. Van Garderen, N.; Clemens, F.J.; Mezzomo, M.; Bergmann, C.P.; Graule, T. Investigation of clay content and sintering temperature on attrition resistance of highly porous diatomite based material. Appl. Clay Sci. 2011, 52, 115-121. [CrossRef]

50. Akhtar, F.; Rehman, Y.; Bergström, L. A study of the sintering of diatomaceous earth to produce porous ceramic monoliths with bimodal porosity and high strength. Powder Technol. 2010, 201, 253-257. [CrossRef]

51. Gregorová, E.; Uhliřrová, T.; Pabst, W.; Diblíková, P.; Sedlářová, I. Microstructure characterization of mullite foam by image analysis, mercury porosimetry and X-ray computed microtomography. Ceram. Int. 2018, 44, 12315-12328. [CrossRef]

52. Liang, X.; Li, Y.; Yang, J.; Wang, Q.; Sang, S.; He, Z. Influence of template strut morphology on the mechanical performance of $\mathrm{SiC}$ reticulated porous ceramics. Ceram. Int. 2020, 46, 16820-16826. [CrossRef]

Publisher's Note: MDPI stays neutral with regard to jurisdictional claims in published maps and institutional affiliations.

(C) 2020 by the authors. Licensee MDPI, Basel, Switzerland. This article is an open access article distributed under the terms and conditions of the Creative Commons Attribution (CC BY) license (http://creativecommons.org/licenses/by/4.0/). 